\title{
Dynamic Model to Reduce the Impact of Climate Change on the Environment and the Economy
}

\author{
Lina Warlina and Sri Listyarini
}

\begin{abstract}
Climate change is a global phenomenon will have a great impact for human life, such as the impact on the environment and the economy. To conduct research on climate change experimentally rather difficult to do, because it takes a long time and substantial funds, so one of the approach is to create a model. The purpose of this study was to develop a model that can be replicated for the response to climate change impacts on environmental and economic aspects. The method used in this research is a dynamic system model to simulate the impact of climate change. The results showed a reduction in the number of vehicles and fuel sold will have an impact on the reduction of $\mathrm{CO}_{2}$ emissions, so it will reduce the incidence of diarrhea and dengue cases and automatically will reduce economic losses.
\end{abstract}

Index Terms-Climate change, environment, dynamic system.

\section{INTRODUCTION}

The development of technology and industry can impact either positive or negative for human life. The positive impact is expected to increase human welfare, but the negative effects can degrade the quality of human life. In addition, the negative impact caused disharmony and environmental balance. The development of technology and the industry has a significant role in the implementation of the development. The increase in population in many respects also encourages industrialization. As a consequence, the amount of raw materials and industrial waste is increasing, both in terms of quality and quantity. Of course, this will have a negative impact on the environment, such as pollution or climate change.

In Indonesia, the impact of extreme weather can be seen from the incompatibility of the changing seasons in various regions. Some regions suffer from drought, while other areas were flooded. This makes a lot of negative effects, especially for farmers who can no longer determine the harvest season so it makes a lot of crop failure, and also impacts on health and the environment. Based on research conducted by Warlina et al. [1], also stated that there has been a climate change in Jakarta.

According to Ellis and Kasyanov (2008) [2], environmental issues are considered quite important is the reduction of water supply for $55 \%$ of the world's population, the loss of around 11,000 species of plants and animals that cause a reduction in $30 \%$ of the world's biodiversity in the

Manuscript received September 24, 2016; revised February 21, 2017.

The authors are with Faculty of Mathematics and Natural Sciences, Indonesian Open University (Universitas Terbuka), Indonesia (e-mail: warlina@ecampus.ut.ac.id, listyarini@ecampus.ut.ac.id). middle of this century, and increasing emissions of carbon dioxide $\left(\mathrm{CO}_{2}\right)$ that cause global climate change. Of the three proposed environmental issues, global climate change is a very important role, as the climate changes affect the two other global environmental problems. The mechanism is climate change affecting environmental factors such as air and soil quality, depletion of the ozone layer, reduction in water quality and quantity, ecosystems function loss and land degradation that ultimately these factors will affect human health. Of course, climate change will also affect the world economy.

To conduct research on climate change experimentally rather difficult to do, because it takes a long time and substantial funds, so the approach is to create a model. Based on this background, this research is done by using a model of system dynamics to analyze the impact of climate change on the environment and the economy. This study is a continuation of the research that has been done [1] by adding variables that have not been accounted for in previous research, namely green open space and industry that is represented with the fuel sales.

The purpose of this study was to develop a model of a dynamic system that can be used as a reference in the response to climate change impacts on environmental and economic aspects. Environmental aspects of this research is the impact on $\mathrm{CO}_{2}$ emissions is also related to temperature and rainfall, while the economic aspect is the loss of material due to illness cases caused by $\mathrm{CO}_{2}$ emissions.

\section{Methods AND MATERIALS}

This study uses a dynamic system approach to analyze the impact of climate change on the environment and the economy, while to analyze the relationship between variables used regression analysis. Software used for regression analysis is MINITAB, and for a dynamic system is VENSIM. Data was used in this research is secondary data that was collected as a time series from 2000-2013.

Dynamic system used to analyze the behavior change aligned with changes in the timing of a complex system [3]. In this study, changes in environmental and economic consequences of climate change. Through a dynamic system can be seen changes in the system primarily to assess the effectiveness of planning policy. Modeling and simulation models as part of a method of dynamic systems also implement several phases of activity, namely making the concept, modeling, simulation models, model validation, as well as policy analysis [4].

\section{ASSUMPTION}


The assumptions used to analyze the impact of $\mathrm{CO}_{2}$ emissions on the environment and sources of $\mathrm{CO}_{2}$, based on previous research conducted by Warlina et al. (2009). All the equations result of Minitab is used in a dynamic system for relationships between variables. Some assumptions are:

- $\mathrm{CO}_{2}$ emissions from residential

According to Bappenas (2008) [5], 1 hectare of green space is able to produce 0.6 tons of oxygen. The amount to be consumed 1,500 residents per day, reduce the temperature of $5-8^{\circ}$ Celsius, reduce noise $25-80$ percent, and $75-80$ percent absorbs pollutant gases. Thus the calculation of the $\mathrm{CO}_{2}$ emissions of the population is the number of population $\mathrm{x}$ $(0.6 / 1500) \times 6 \times 365$.

- $\mathrm{CO}_{2}$ emissions from vehicles

The data obtained is the total emissions of $\mathrm{HC}$ (hydrocarbon) of the vehicle and the number of vehicles (BPS, 1995-2008) [6]. So for the average emissions of the vehicle $\mathrm{HC}=\mathrm{HC}$ emissions (tons/year)/number of vehicles = 0.058402

$\mathrm{CO}_{2}$ emissions of the vehicle $=44 / 16 \mathrm{x}$ emissions $\mathrm{HC}$.

- $\mathrm{CO}_{2}$ emissions from fuel

Assumption of fuel has its chain $\mathrm{C}$ is eight. The fuel is converted to $\mathrm{CO}_{2}=\left(1\right.$ mole fuel $=114 \mathrm{~g} ; 1$ mole of $\mathrm{CO}_{2}=44$; specific gravity of fuel $=0.8)$. Heavy fuel oil $=$ fuel sales $\mathrm{x}$ 0.8 .

$\mathrm{CO}_{2}$ emissions from fuel = heavy fuel $\mathrm{x} 44 / 114$

- The $\mathrm{CO}_{2}$ emissions of green open space [7], [8]

1) Ratings ability green open space to absorb carbon:

Green open space broad search and the potential established, counting standing stock (wood biomass).

The quantity of biomass, calculated from the extensive green open space (ha) x potential enforce $\left(\mathrm{m}^{3} / \mathrm{ha}\right)$.

2) The intensity of the pick-test enforce (height and diameter) of $5 \%$.

3) Standing stock (the amount of biomass) = extensive green area $x$ the average volume enforces $\left(\mathrm{m}^{3} / \mathrm{ha}\right)$ the footage.

4) Total carbon $=$ total biomass $x 0.5$

5) Total $\mathrm{CO}_{2}$ is sequestered carbon $\mathrm{x} 3.6667=$ total Stand value is calculated based on the average stand for landscaping in Jakarta in 2010 , i.e. by $62 \%$, while the trailer is also based on the average of 2010 amounted to $50.00667 \mathrm{~m}^{3} / \mathrm{ha}$.

\section{RESUlTS AND DISCUSSION}

A dynamic system model that constructed as a simple model, consist of the sub-models of population, sub-models of $\mathrm{CO}_{2}$, and sub-models of climate change impacts on the reduction of water and cases of illness (diarrhea and dengue). The stock flow diagram (SFD) of the models is shown in Fig. 1.

A growing population, increasing number of vehicles, increasing number of industries and increasing the amount of fuel usage will lead to the increase of $\mathrm{CO}_{2}$ in the air. However, the increase in $\mathrm{CO}_{2}$ will be reduced when there is a lot of green open space in the neighborhood.

In this study, the increase in $\mathrm{CO}_{2}$ is assumed from the population, the number of vehicles, fuel sales and industry. However, the industry's influence on the increase of $\mathrm{CO}_{2}$ is not direct, but are represented in the sale of fuel. Because based on the number of existing industries in Jakarta, not all of these industries emit $\mathrm{CO}_{2}$.

Increased $\mathrm{CO}_{2}$ in the air will be led to the rise in temperature and rainfall, so that cause of climate change. Climate change will have an impact on the reduction of clean water sources, which can also lead to increased of diarrhea, while on the other hand, with increased rainfall and temperatures will impact the increase in dengue disease. The existence of cases of these diseases significantly, would cause economic losses.

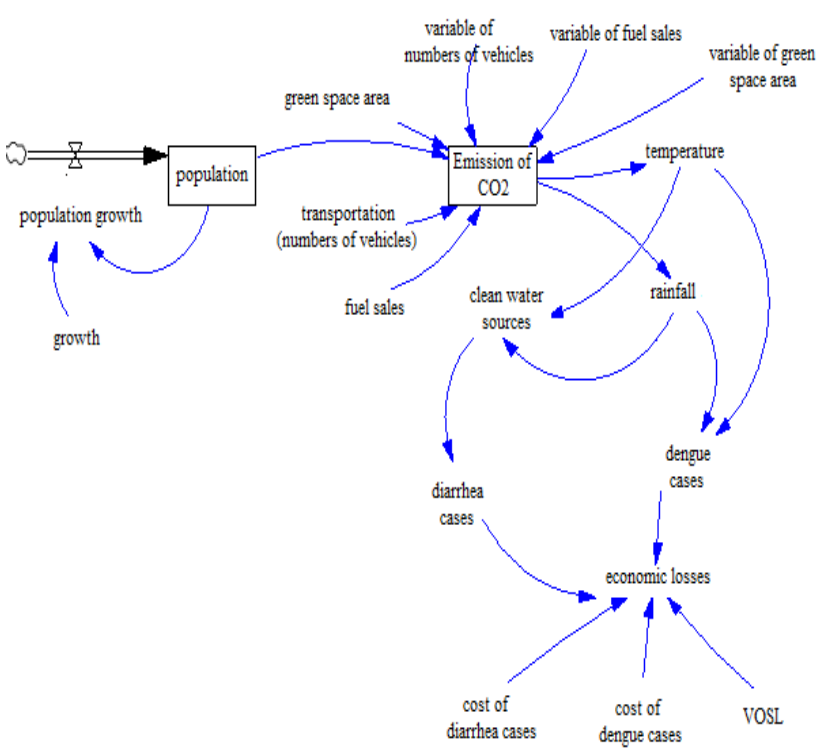

Fig. 1. The SFD of climate change impact on economic and environmental.

To run the dynamic model, the relationship of the variable should be stated in the equation that come from the relationship between variables through regression analysis. Some relationship of each of these variables is as follows:

- Temperature $=26.723+0.000000$ Total Emission of $\mathrm{CO}_{2}$

- Dengue cases $=11216+89$ temperatures

- Rainfall = $1945+0.000009$ Total Emission of $\mathrm{CO}_{2}$

- Dengue cases $=59519+3.86$ rainfall - 1927 temperature

- Water sold $=-461634871-5938$ rainfall +26582237 Temperature

- Dengue cases = 1034919 - 0.00248 water sold

- Total Emission of $\mathrm{CO}_{2}=-13143676+3.728$ populations

- Total Emission of $\mathrm{CO}_{2}=6254506+1.263$ numbers of Vehicles

- Total Emission of $\mathrm{CO}_{2}=5691281+407697$ fuels sales

- Total Emission of $\mathrm{CO}_{2}=39614493-0.973$ the area of green open space

- Total Emission of $\mathrm{CO}_{2}=0.000000+0.1606$ numbers of vehicles +308772 fuels sales -0.005684 the area of green open space +0.8760 populations.

It appears that almost all of the variables have a positive impact on the $\mathrm{CO}_{2}$ emission increases unless extensive green open space. The higher the green open space, it will further reduce the $\mathrm{CO}_{2}$ emissions. It is possible, because one of the functions of green space that can absorb the $\mathrm{CO}_{2}$.

Based on the analysis of the regression equations, it appears that the effect of $\mathrm{CO}_{2}$ emissions on temperature is 
very small, so it does not appear in the equation. Based on IPCC research (The Working Group I contribution to the IPCC's Fifth Assessment Report) considers new evidence of climate change based on many independent scientific analyses from observations of the climate system, paleoclimate archives, theoretical studies of climate processes and simulations using climate models stated that the globally averaged combined land and ocean surface temperature data as calculated by a linear trend, show a warming of 0.85 [0.65 to $1.06{ }^{\circ} \mathrm{C}$, over the period 1880 to 2012 [9]. Thus the effect of $\mathrm{CO}_{2}$ emissions in 14 years in this study did not look significantly influence the temperature increase. Another case with the effects of $\mathrm{CO}_{2}$ emissions on rainfall, although small, but seemed to influence on rainfall.

When analyzed individually the effect of temperature, rainfall and the dengue cases, it appears that the two variables are significant. However, when analyzed simultaneously influence, the influence of rainfall had a positive effect, while the effect of temperature has a negative impact. That is, the rainfall impact is greater than the temperature of the dengue cases.

For a relationship to water sold by rainfall, it appears that when rainfall is high, then the clean water sold is reduced. This is consistent with the fact that when rainfall is high, they do not need to buy water. They can collect rainwater for various needs. Another case with the effect of temperature on water sold, the higher the temperature, the water sold also rose.

Relations clean water sold in cases of diarrhea has negative relationships. When water sold higher, then it will be less cases of diarrhea. This is in accordance with reality, increased use of clean water, the environment becomes clean, cases of diarrheal disease will be less.

\section{A. The Results of Dynamic Systems Model}

Until 2025, the Jakarta population growth will continue to rise to approximately 13 million if they do not do anything policies (do nothing), as shown in Fig. 2. In addition, there is also an increase in total $\mathrm{CO}_{2}$ emissions coming from the number of vehicles, people, sales of fuel and green open space. The graph in fairly sharp increase in $\mathrm{CO}_{2}$ emissions until 2025.

On the other hand, $\mathrm{CO}_{2}$ emissions also have an impact on the number of dengue cases and the amount of water consumed. The increased rainfall and temperatures will result in an increase in dengue cases. Until 2025, dengue cases will increase to approximately 125,000 people when no specific policies. Similarly to the case of diarrheal diseases. Until 2025 , cases of diarrheal diseases are also increasing. The number of cases of diarrhea was higher than the dengue disease.

Unlike the other variables that increase steadily, clean water used variable to decrease until 2025. This is understandable, because of the increasing water supplies are depleted, so that clean water sold is also diminishing (Fig. 2). The entire increase in the variables in this study, of course, would impact on the economy. The value of Indonesian public life or the Value of Statistical Life (VOSL) is based on research by Susandi (2004)[10] in the amount of US $\$ 144,000$ or approximately Rp.1.944.000.000,- (rate of Rp.
13.500,-). In addition, health care costs are not only diarrhea and dengue fever are calculated based on the cost of treatment and care, but also the losses caused due to people unable to perform his job during an illness related to the wages these patients. The economic losses caused two cases of the disease as in Fig. 2. If there is no policy to reduce emissions, the economic loss will reach about Rp.1.2 trillion in 2025. This value is quite high, so we need a policy to reduce this value.
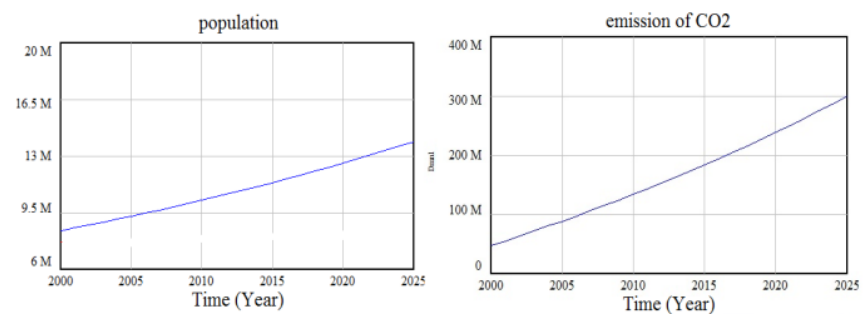

dengue cases

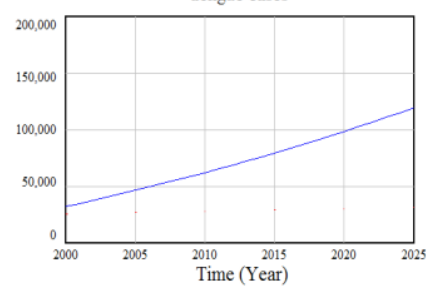

diarrhea cases
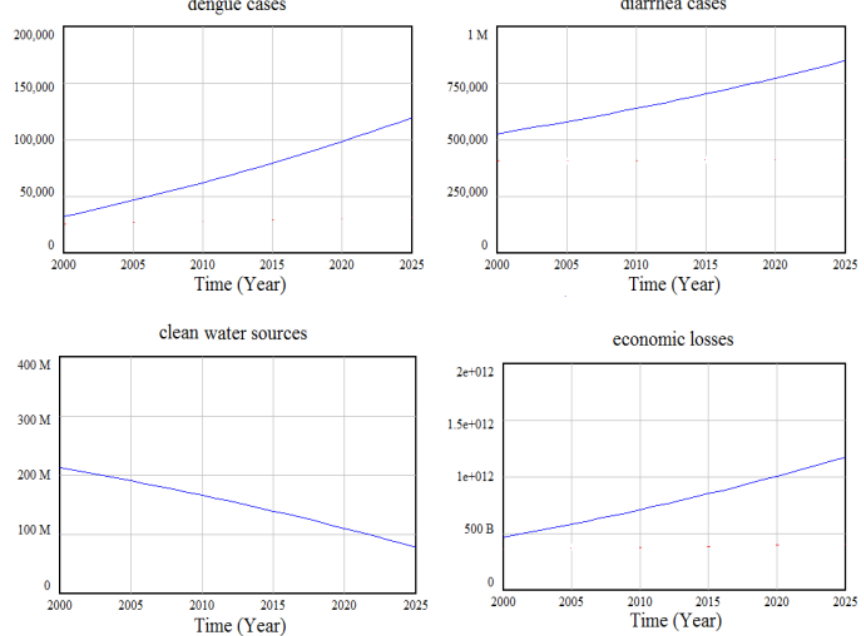

Fig. 2. Result of a dynamic system.

\section{B. Results of Simulation Model}

Simulations carried out until 2025 at the rate of population growth, a reduction in fuel, reduction in the number of vehicles and increase green open space. Impacts are analyzed, that is to $\mathrm{CO}_{2}$ emissions, cases of dengue, diarrhea and economic losses. Analysis of simulated data is done by value in 2020 and 2025. It is based on a binding international agreement as a shared commitment to reducing the world's greenhouse gas emissions were being applied after 2020. The meeting also resulted in the Paris Agreement, which mentions countries of the world committed to keeping the threshold limit global temperature increase to below $2^{\circ} \mathrm{C}$ and trying to suppress until $1,5^{\circ} \mathrm{C}$ [11]. Therefore, the analysis conducted in 2020 and the next 5 years, that is 2025.

\section{1) Simulation of changes in the rate of population growth}

Based on population data from 2000-2013, the population growth rate is $2.04 \%$. Although this figure is not so high, but the government should be able to anticipate that population growth not to to rise again. This can be done with the ratification of policy of Family Planning Program, so that population growth can be suppressed. Assuming the existence of policy of family planning program which will suppress the population growth rate of $1.5 \%$ and $1.75 \%$, this policy will have an impact also on $\mathrm{CO}_{2}$ emissions and the 
impact on other variables. The simulation results, changes in population growth as shown in Fig. 3.

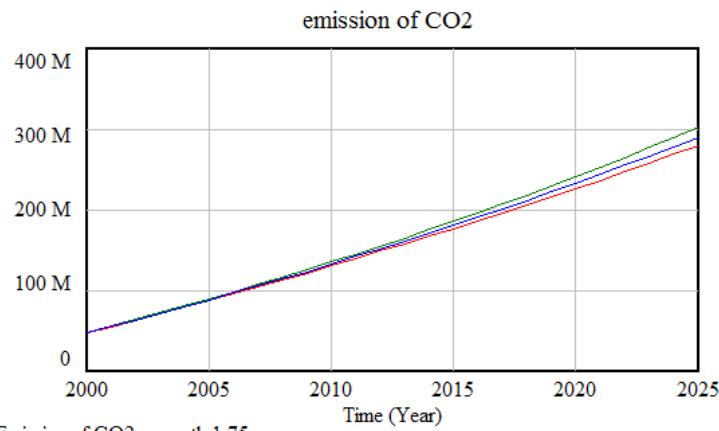

Emission of $\mathrm{CO} 2$ : growth 1.75

Emission of $\mathrm{CO} 2$ : growth 1.5
Emission of $\mathrm{CO} 2$ : normal growth

Emission of $\mathrm{CO} 2$ : current

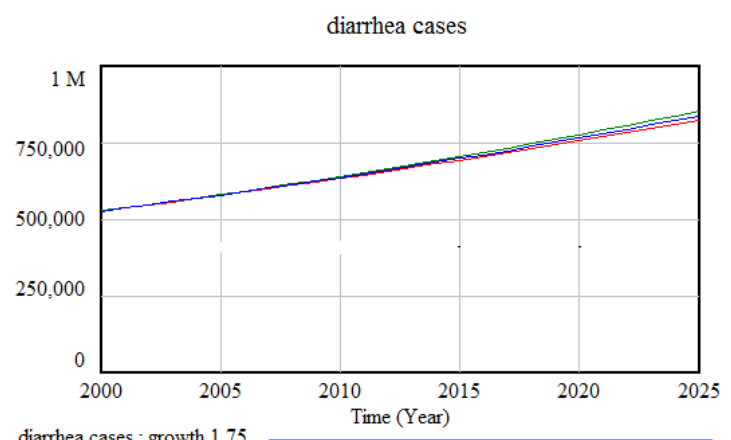

diarrhea cases : growth 1.75

diarrhea cases : normal growth

diarrhea cases : current

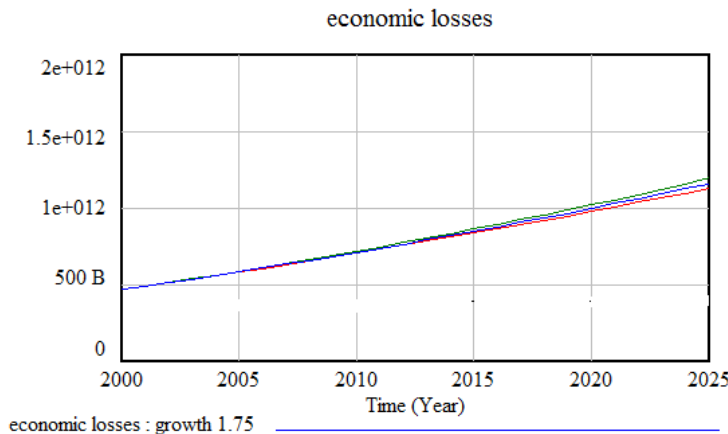

economic losses : growth 1.75

economic losses : growth 1.5

economic losses : normal growth

economic losses : current

Fig. 3. The effect of population growth in $\mathrm{CO}_{2}$ emission, diarrhea cases and economic losses.

Based on the resulting graph of the simulation, it appears that the reduction of population growth rate of $1.5 \%$ and $1.75 \%$ has little effect on $\mathrm{CO}_{2}$ emissions, cases of dengue fever, diarrhea and economic losses. When calculated based on the value, the percentage of reduction in Table I.

When simulation was done decline in the population growth rate of $1.5 \%$, then by 2025 there will be a reduction in $\mathrm{CO}_{2}$ emissions significant, that is $7.66 \%$. Likewise for other variables, a reduction varied.

\section{2) Simulation of reduction in fuel sales}

Simulation on fuel sales did with the reduction of fuel sales by $5 \%, 10 \%$ and $30 \%$. The reduction had a significant impact on $\mathrm{CO}_{2}$ emissions, the incidence of diarrhea, dengue cases and economic loss.

Based on simulation, fuel sales reduction of $30 \%$ is a very significant reduction. This can be seen in Table II.
The result of simulation can be described as a picture in Fig. 4.

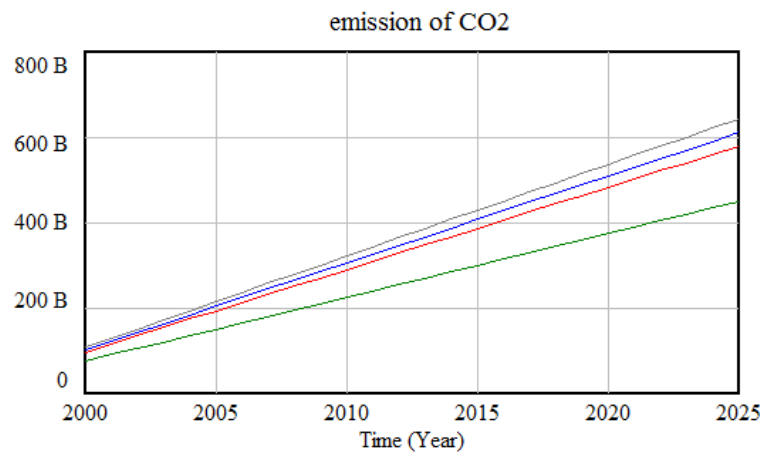

emission of $\mathrm{CO} 2$ : reduction in fuel $5 \%$

emission of $\mathrm{CO} 2$ : reduction in fuel $10 \%$

emission of $\mathrm{CO} 2$ : reduction in fuel $30 \%$

emission of $\mathrm{CO} 2$ : current

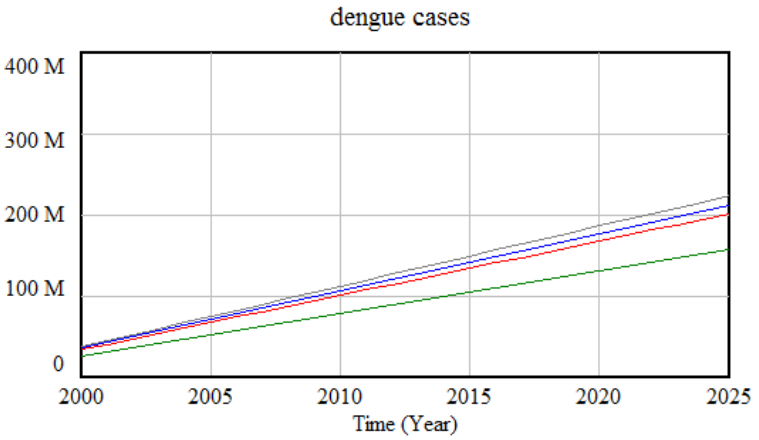

dengue cases : reduction in fuel $5 \%$

dengue cases : reduction in fuel $10 \%$

dengue cases : reduction in fuel $30 \%$

dengue cases : current

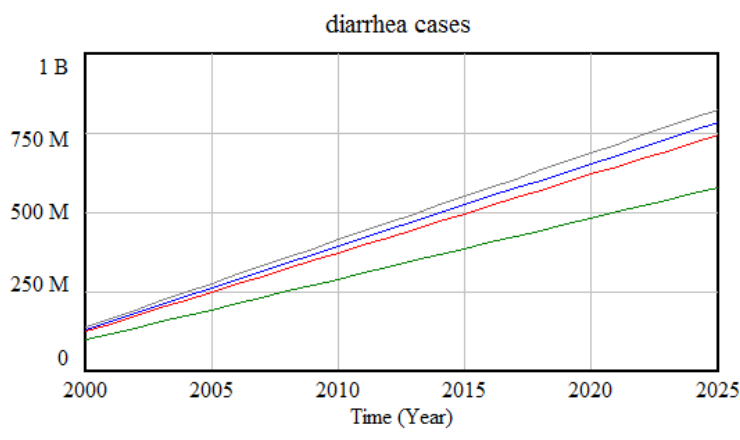

diarrhea cases : reduction in fuel $5 \%$

diarrhea cases : reduction in fuel 10\%

diarrhea cases : reduction in fuel $30 \%$

diarrhea cases : current

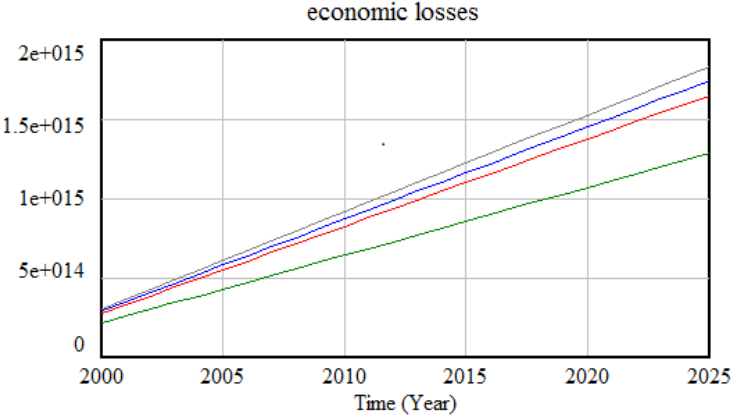

economic losses : reduction in fuel $5 \%$

economic losses : reduction in fuel $10 \%$

economic losses : reduction in fuel $30 \%$

economic losses : current

Fig. 4. The effect of reduction in fuel sales in $\mathrm{CO}_{2}$ emission, dengue cases, diarrhea cases and economic losses. 
TABLE I: SimULATION RESUlTS OF THE IMPACT OF POPULATION GROWTH

\begin{tabular}{c|c|c|c|c|c|c|c|c}
\hline \hline $\begin{array}{c}\text { Growth } \\
(\%)\end{array}$ & \multicolumn{2}{|c|}{ Reduced $\mathrm{CO}_{2}$ emission (\%) } & \multicolumn{2}{c|}{ Reduced economic losses (\%) } & \multicolumn{2}{c}{ Reduced diarrhea cases (\%) } & \multicolumn{2}{c}{ Reduced dengue cases (\%) } \\
\hline & 2020 & 2025 & 2020 & 2025 & 2020 & 2025 & 2020 \\
\hline 1,75 & 3.44 & 4.22 & 1.04 & 1.13 & 2.50 & 3.48 & 2.90 & 3.68 \\
\hline 1,5 & 6.27 & 7.66 & 1.95 & 2.55 & 3.16 & 3.68 \\
\hline \hline
\end{tabular}

TABLE II: SiMULATION RESUlTS OF THE IMPACT OF REDUCTION IN FUEL SALES

\begin{tabular}{|c|c|c|c|c|c|c|c|c|}
\hline \multirow[t]{2}{*}{$\begin{array}{c}\text { Reduction in fuel sales } \\
(\%)\end{array}$} & \multicolumn{2}{|c|}{$\begin{array}{c}\text { Reduced } \mathrm{CO}_{2} \text { emission } \\
(\%)\end{array}$} & \multicolumn{2}{|c|}{ Reduced economic losses (\%) } & \multicolumn{2}{|c|}{ Reduced diarrhea cases (\%) } & \multicolumn{2}{|c|}{ Reduced dengue cases (\%) } \\
\hline & 2020 & 2025 & 2020 & 2025 & 2020 & 2025 & 2020 & 2025 \\
\hline 5 & 5.00 & 5.00 & 5.01 & 5.00 & 4.99 & 4.99 & 4.99 & 5.00 \\
\hline 10 & 9.99 & 10.00 & 9.99 & 9.99 & 9.99 & 9.99 & 10.00 & 9.99 \\
\hline 30 & $\begin{array}{c}29.9 \\
8\end{array}$ & 29.98 & 29.98 & 29.98 & 29.96 & 29.97 & 29.98 & 29.98 \\
\hline
\end{tabular}

TABLE III: SIMULATION RESULTS OF THE IMPACT OF REDUCTION IN NUMBER OF VEHICLES

\begin{tabular}{|c|c|c|c|c|c|c|c|c|}
\hline \multirow{2}{*}{$\begin{array}{c}\text { Reduced } \\
\text { vehicles }(\%)\end{array}$} & \multicolumn{2}{|c|}{ Reduced $\mathrm{CO}_{2}$ emission (\%) } & \multicolumn{2}{|c|}{ Reduced economic losses (\%) } & \multicolumn{2}{|c|}{ Reduced diarrhea cases (\%) } & \multicolumn{2}{|c|}{ Reduced dengue cases (\%) } \\
\hline & 2020 & 2025 & 2020 & 2025 & 2020 & 2025 & 2020 & 2025 \\
\hline 5 & 0.37 & 0.36 & 0.25 & 0.26 & 0.15 & 0.16 & 0.32 & 0.31 \\
\hline 10 & 0.75 & 0.72 & 0.51 & 0.52 & 0.30 & 0.33 & 0.63 & 0.63 \\
\hline 25 & 1.88 & 1.80 & 1.27 & 1.30 & 0.75 & 0.82 & 1.56 & 1.57 \\
\hline
\end{tabular}

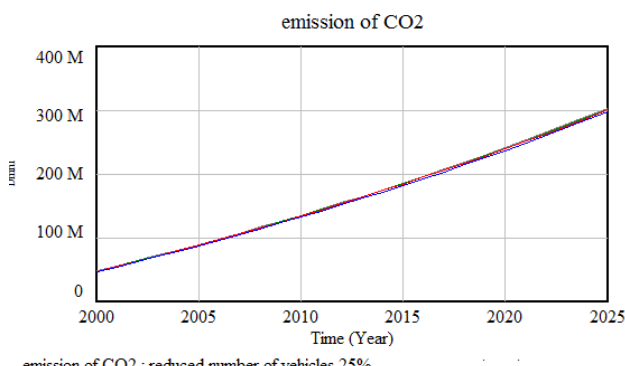

emission of $\mathrm{CO} 2$ : reduced number of vehicles $25 \%$ emission of $\mathrm{CO} 2$ : reduced number of vehicles $10 \%$ emission of $\mathrm{CO} 2$ : reduced number of vehicles $5 \%$ emission of $\mathrm{CO} 2$ : normal

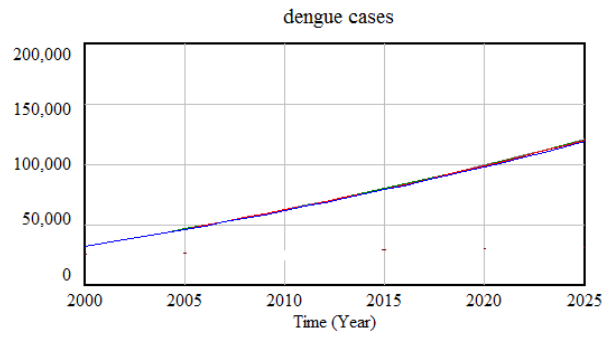

dengue cases : reduced number of vehicles $25 \%$ dengue cases : reduced number of vehicles $10 \%$ dengue cases : reduced number dengue cases : current

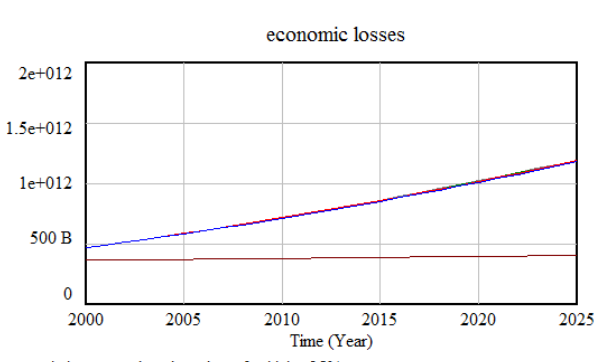

economic losses : reduced number of vehicles $25 \%$ economic losses : reduced number of vehicles $10 \%$ economic losses : normal

Fig. 5. The effect of reduction in number of vehicles in $\mathrm{CO}_{2}$ emission, dengue cases and economic losses.
Based on Table II, a reduction in fuel sales will have an impact similar to the reduction of other variables. This is causing the influence of other variables little effect on $\mathrm{CO}_{2}$ emissions. It can be seen from the equation, namely the relationship of $\mathrm{CO}_{2}$ emissions with fuel sales, the number of vehicles and extensive green open space. Thus, policies related to the reduction of fuel urgently need to be followed, because it will greatly affect other impacts.

\section{3) Simulated reduction in the number of vehicles}

Simulated reduction of the number of vehicles taken to a reduction of $5 \%, 10 \%$ and $25 \%$. Based on the resulting graph in Fig. 5, the reduction in the number of vehicles by 5\%, $10 \%$ and $25 \%$ is very little difference, so the graph like a pile.

When analyzed based on the data, the reduction actually occurs, but very small. This can be seen in Table III. Reduction in the number of vehicles by $25 \%$ gives a significant impact even though it still looks a little influence, is still below $2 \%$. Thus, the policy of reducing the number of vehicles can be applied to a substantial reduction in order to look the effect significantly. Reduction in the number of vehicles is expected to occur quite large if public transportation is provided by the government of Jakarta has been perceived safety and convenience. A Jakarta government program that will provide a fast train or MRT (Mass Rapid Tranportation) as one tool public transportation in Jakarta is expected to reduce the number of private vehicles is quite significant and ultimately overcome traffic congestion and reduce $\mathrm{CO}_{2}$ emissions.

\section{4) Simulation addition of green open spaces}

Increase green open space simulation was done by 2 times, 3 times and 100 times. Based on simulation results in Fig. 6, the addition of green space area is almost no effect.

Likewise, when the data were analyzed based on the 
simulation results, there is little difference, as in Table IV.

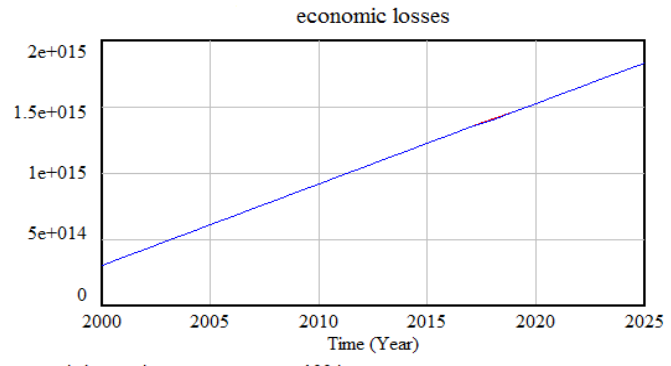

economic losses : increase green space 100 times

economic losses : increase green space 3 times

economic losses : increase green space 2 times

economic losses : current

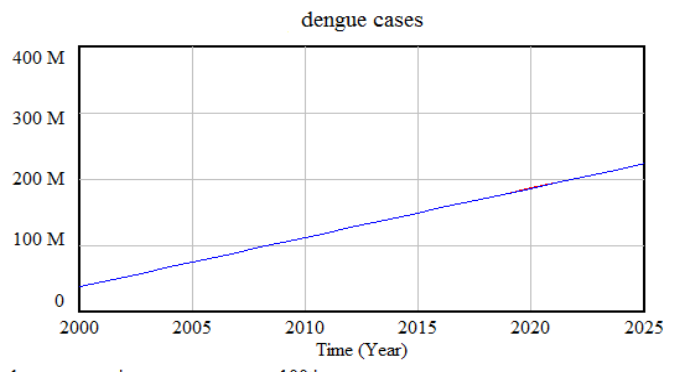

dengue cases : increase green space 100 times

dengue cases : increase green space 3 times

dengue cases : increase green space 2 time

dengue cases : currer

Fig. 6. The effect of increase green open space in economic losses and dengue cases.

TABLE IV: SIMULATION RESULTS OF THE INCREASE THE GREEN OPEN SPACE

\begin{tabular}{c|c|c|c|c|c|c}
\hline \hline $\begin{array}{c}\text { Addition } \\
\text { of green } \\
\text { open } \\
\text { space (\%) }\end{array}$ & \multicolumn{2}{|c|}{$\begin{array}{c}\text { Reduced } \mathrm{CO}_{2} \\
\text { emission (\%) }\end{array}$} & \multicolumn{2}{|c|}{$\begin{array}{c}\text { Reduced } \\
\text { economic } \\
\text { losses (\%) }\end{array}$} & \multicolumn{2}{|c}{$\begin{array}{c}\text { Reduced } \\
\text { dengue cases } \\
(\%)\end{array}$} \\
\hline & 2020 & 2025 & 2020 & 2025 & 2020 & 2025 \\
\hline 300 & 0.00 & 0.00 & 0.00 & 0.00 & 0.00 & 0.00 \\
\hline 10000 & 0.05 & 0.05 & 0.05 & 0.05 & 0.05 & 0.05 \\
\hline \hline
\end{tabular}

Table IV summarizes the addition of green open space of 100 times or $10,000 \%$ will have an impact though it is still quite significant. Additions spacious green open space has influenced smallest to $\mathrm{CO}_{2}$ emissions. It is also possible, because in reality, the current extensive green space in Jakarta is still around 9,84\% [12], so in order to reduce $\mathrm{CO}_{2}$ emissions, should be done extensive addition of green open space is quite high. Meanwhile, Indonesia has already had the regulation in green areas that is Indonesian Law No. 26/2007, which stated that the ideal green area in big cities like Jakarta is $30 \%$ of the total city areas [13].

\section{CONCLUSIONS AND RECOMMENDATIONS}

The impact of climate change on illness and economic losses can be demonstrated by using a dynamical system. Through simulations using this system can predict the impact of climate change for several years to come.

The smaller the population growth rate, the greater the reduction of $\mathrm{CO}_{2}$. Similarly to the economic loss, the smaller the rate of population growth, the reduction of the greater economic loss. In addition, reduction in the number of vehicles and fuel sales will have an impact on the reduction of $\mathrm{CO}_{2}$ emissions, so it will reduce the cases of diarrhea and dengue cases and automatically will reduce economic losses. Also, the addition of green open space should be high enough when it will have an impact on the reduction of $\mathrm{CO}_{2}$ emissions.

For further research, $\mathrm{CO}_{2}$ emissions can be calculated by adding another variable that has not been included in this study, for example, the industry in more details.

\section{REFERENCES}

[1] L. Warlina, S. Listyarini, H. Sugiarti, E. N. Kusumaningrum, and H. Siregar, "Model dampak perubahan iklim terhadap sumberdaya air dan kasus penyakit (Studi Kasus DKI Jakarta)," Universitas Terbuka, Jakarta, 2009

[2] M. Ellis and P. Kasyanov. (2008). Proposal to the world. [Online]. Available:

http://www.globalcitizensforpeace.com/subtopic/proposal_to_the_wo rld.htm

[3] A. Ford, "Modeling the environment, an introduction to system dynamics models of environmental systems," USA: Island Press, 1999.

[4] E. Muhammadi, B. Aminullah, and B. Soesilo, "Analisis sistem dinamis - lingkungan hidup, sosial, ekonomi, manajemen," Jakarta: UMJ Press, Pusat Studi Kebijakan dan Dinamika Sistem UMJ, 2001.

[5] Bappenas. (2004). Perbaikan Pengelolaan Sumber Daya Alam Dan Pelestarian Fungsi Lingkungan Hidup. [Online]. Available: http://www.bappenas.go.id/index.php?module=Filemanager $\&$ func $=$ do wnload \&pathext $=$ ContentExpress $/$ RPJMN2004/\&view $=$ Bab $\% 2032 \%$ 20(SDA\%20dan\%20LH).doc

[6] BPS-Statistics of DKI Jakarta Province, Jakarta in Figures 1996-2008, BPS: Jakarta, 1996-2008.

[7] IPCC. (Dec. 10, 2007). Climate change 2007: The physical science basis. Summary for policymakers. Intergovernmental Panel on Climate Change, Geneva. [Online]. Available: http://unfccc.int/files/meetings/cop_13/press/application/pdf/sekilas_t entang_perubahan_iklim.pdf

[8] T. Waryono, "Potensi Ruang Terbuka Hijau Dalam Penurunan Gas Emisi di Jakarta," Dec. 15, 2015.

[9] IPCC, “2013: Summary for policymakers," Climate Change 2013: The Physical Science Basis. Contribution of Working Group I to the Fifth Assessment Report of the Intergovernmental Panel on Climate Change.

[10] A. Susandi, "The impact of International greenhouse gas emission reduction on Indonesia," Dissertation zur Erlangungdes Doctorgrades der Naturwissenschaften im Fachbereich Geowissenschaften der Universitat Hamburg, 2004.

[11] Firmansyah. (Dec. 2015), Beberapa Kesepakatan Konferensi Perubahan Iklim Paris. [Online]. Available: http://internasional.kompas.com/read/2015/12/13/09090031/Beberapa .Kesepakatan.Konferensi.Perubahan.Iklim.Paris

[12] S. Listyarini, L. Warlina, E. Indrawati, and T. Pardede, "Optimization model for predicting green area in Jakarta to minimize impacts of climate change," The Sustainable City IX, vol. 191, 2014.

[13] Undang-undang Republik Indonesia Nomor 26 Tahun 2007 tentang Penataan Ruang. (2007). [Online]. Available: http://www.bktrn.org/public/UU_No26_2007.pdf

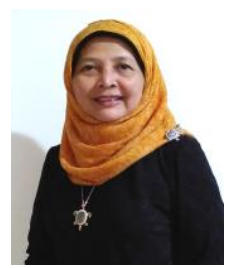

Lina Warlina was born on January 7, 1961 in Padang Panjang, West Sumatra, Indonesia. She received her bachelor in chemistry from University of Indonesia in 1985; her master degree in education from Simon Fraser University, Canada in 1990 and her doctor in environmental science from Bogor Agriculture University, Indonesia in 2009.

She is currently a lecturer at Faculty of Mathematic and Natural Sciences in Indonesian Open University (Universitas Terbuka). He has served for 32 years in Universitas Terbuka. Her fields of specialization include environmental modeling and simulations. She has journal publications in Journal of Chemica Pharmatica Research, Jurna Matematik, Science dan Teknologi and Jurnal Organisasi dan Management. 


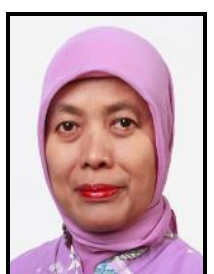

Sri Listyarini was born on April 07, 1961 in Jakarta, Indonesia. She received bachelor in chemistry from the Faculty of Mathematics and Natural Sciences, University of Indonesia in 1985 and the master in management of distance education from the Faculty of Education, Simon Fraser University, Vancouver, Canada in 1990. She received her doctor in management of environmental and natural resources, from Bogor
Agriculture University, Indonesia in 2009. She has served for 30 years in Indonesia Open University (Universitas Terbuka) as a lecturer in the Faculty of Mathematic and Natural Sciences. Her fields of specialization include environmental and ecological system modeling and simulations, especially air pollution modeling and simulations. She has journal publication in Der Pharma Chemica, the Sustainable City, and Jurnal Matematika, Sains, dan Teknologi. 